\title{
Ongoing mumps outbreak in Novi Sad, the autonomous province of Vojvodina, Serbia, January to April 2012
}

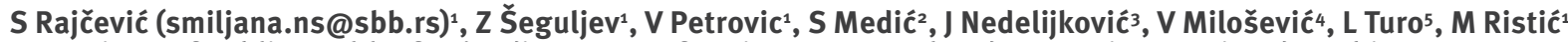

1. Institute of Public Health of Vojvodina, Centre for Disease Control and Prevention, Novi Sad, Serbia

2. Institute of Public Health, Sremska Mitrovica, Serbia

3. Institute for Virology, Vaccines and Sera Torlak, Belgrade, Serbia

4. Institute of Public Health of Vojvodina, Centre for Virology, Novi Sad, Serbia

5. Institute for Student Health Care, Novi Sad, Serbia

Rajčević S, Šeguljev Z, Petrovic V, Medić S, Nedelijković J, Milošević V, Turo L, Ristić M. Ongoing mumps outbreak in Novi Sad, the autonomous province of Vojvodina, Serbia, January to April 2012. Euro Surveill. 2012;17(19):pii=20169. Available online: http://www.eurosurveillance.org/ViewArticle. aspx?Articleld $=20169$

From 16 January to 30 April 2012, a total of 119 cases of mumps were notified in Novi Sad, Serbia. Of these cases, $89(75 \%)$, were among students. The average age of cases was 22 years-old (range 3-37). The outbreak is still ongoing in Novi Sad and is spreading to other parts of the Vojvodina province. As of 30 April, 209 cases have been notified in the province among those 119 from Novi Sad.

Resurgent outbreaks of mumps have recently been reported from several European Union and neighbouring countries [1-7]. Here we report on an ongoing mumps outbreak in Novi Sad, capital of the Autonomous Province of Vojvodina, Serbia. Similarly to outbreaks in England, Netherlands and Israel in recent years, the present one affects mainly young adults [8-10].

Mumps is a vaccine-preventable disease caused by a paramyxovirus. The typical clinical picture comprises fever, headache, malaise, painful unilateral or bilateral parotid swelling and complications such as orchitis, meningitis and encephalitis occur. Mumps is a notifiable disease in Serbia.

\section{Outbreak description}

On 16 January 2012, the Institute for Student Health Care in Novi Sad reported two cases of mumps among students who study at University of Novi Sad, to the Institute of Public Health of Vojvodina. These students had spent the Christmas and New Year holidays in Bosnia and Herzegovina, where a large outbreak of mumps is ongoing $[7,11,12]$.

Novi Sad is the second largest city in Serbia, capital of the northern Serbian province of Vojvodina, and the administrative centre of the South Bačka district. The urban area has a population of 221,854 , while its municipal area has a population of 335,701 [13].
Since 25 January, the Public Health Service in Novi Sad has been registering further cases of mumps among students and residents of the town. These had not travelled during the maximum length of the incubation period, 25 days. Here we provide detailed information about cases up to 30 April.

\section{Case definition}

An imported case of mumps is defined as any person in Novi Sad with a history of painful swelling of one or both parotid glands without any other apparent cause, epidemiologically linked with a case of mumps in Bosnia and Herzegovina within the maximum length of the incubation period.

A possible case is defined as a case with a clinical picture compatible with mumps diagnosed by a physician after 16 January 2012, in Novi Sad.

An epidemiologically linked case is defined as any person in Novi Sad meeting the clinical criteria and epidemiologically linked with a confirmed or imported case of mumps.

A confirmed case is defined as a case with symptoms compatible with mumps and with serological confirmation of IgM mumps antibodies and/or verification by PCR from throat swabs in any person not vaccinated in the previous two months.

By 30 April, a total of 119 cases had been reported from Novi Sad to the Institute of Public Health of Vojvodina of which 25 were considered as imported (Figure). In total, 32 cases were laboratory-confirmed (IgM or PCRpositive), genotyping was not performed. 87 cases were clinically diagnosed as either possible cases $(n=45)$ or epidemiologically linked cases $(n=42)$.

The average age of cases was 22 years. The youngest case was three years old and the oldest was 37 years 
of age. Cases occurred most frequently in the 20 to 29 year-olds age group $(n=91 ; 76 \%)$. There were more male $(n=70)$ than female $(n=49)$ cases. Thirteen cases were hospitalised with complications, nine with orchitis and four with pancreatitis. In total $13 \%$ of males over 15 years old contracted orchitis.

For 86 cases, there was no information or data about previous mumps vaccination. The remaining 33 cases were vaccinated, among which 29 had received two doses of measles-mumps-rubella (MMR) vaccine. Four were vaccinated with only one dose of MMR.

\section{Public health response}

The public health authorities of Vojvodina, advised the paediatric health services to revisit immunisation records of all children between one and 14 years of age and to call-in and vaccinate children who had not received the recommended $M M R$ vaccine for temporary reasons, as soon as possible.

Other epidemic control measures include, disseminating information to health services and the general public about the mumps outbreak by the public health authorities, isolating infected persons and limiting contact with them. Furthermore, persons who had been in contact with those infected, are placed under medical surveillance and receive information about the disease.

\section{Discussion and conclusion}

Immunisation against mumps was introduced in Serbia in 1986. Between 1996 and 2006, a combined MMR vaccine was administered according to a two-dose schedule at the ages of 12 months and 12 years but no later than 14 years of age. In 2006, the schedule was changed and the second dose is now administered at the age of seven.

In Serbia, before vaccination against mumps became part of the Serbian childhood vaccination schedule, mumps occurred frequently among children 5 to 9 years of age. Since the introduction of mumps vaccine into the routine childhood immunisation schedule, the number of cases has declined dramatically from 240 in 1982 , to 30 in 1994 [14-16].

In Novi Sad, after introduction of the MMR vaccine into the national schedule in 1996, a total of 36 cases of mumps were registered between 1996 and 2011. The incidence rate was low and ranged from zero per 100,000 population in the period from 2007 to 2009 to 3.3 per 100,000 population in 2003 [17].

The importation of mumps cases from Bosnia and Herzegovina contributes to the epidemic spread of mumps in 2012 in Novi Sad and further on in Vojvodina. Ill students infected in Novi Sad probably represent a

\section{FIGURE}

Cases of mumps by calendar week of symptom onset, Novi Sad, Serbia 2012 ( $n=119)$

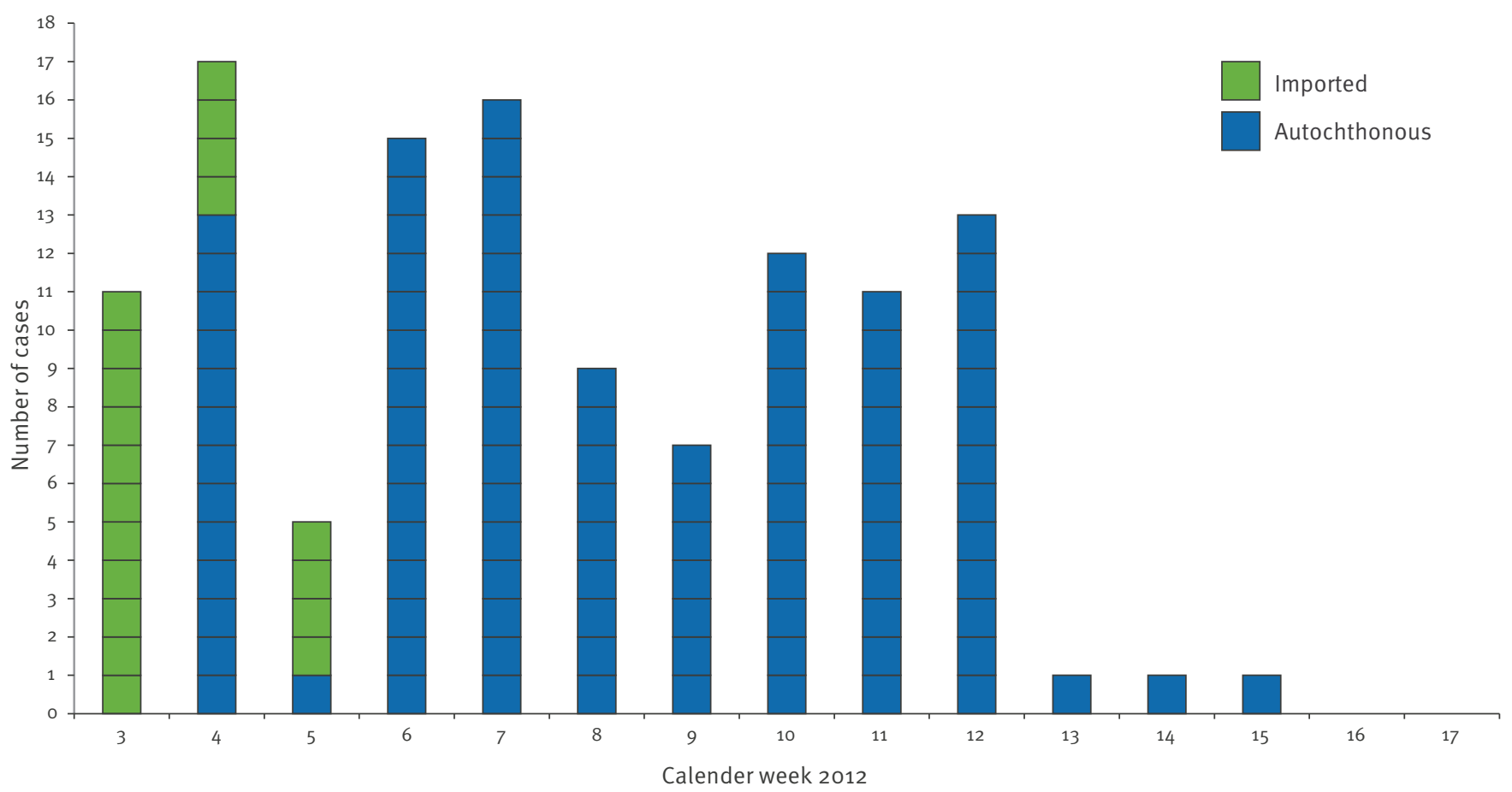


source for the further spread of the outbreak to other towns, all over Vojvodina Province, where there are a number of susceptible people in age groups that were not targeted for mumps vaccination as children and adolescents. In total, from 16 January to 30 April 2012, 209 cases of mumps were registered in Vojvodina among those 119 from Novi Sad, with the majority of cases in 20 to 29 year-olds.

The fact that new outbreaks of mumps take place decades after vaccine introduction, and the occurrence of cases among young adults and previously immunised persons, indicate the need for further improvement of prevention strategies. The complication rate early in this outbreak of $13 \%$ is slightly higher than that in the literature and also highlights the need for attention $[18,19]$.
References

1. Whyte D, O'Dea F, McDonnell C O'Connell NH, Callinan $\mathrm{S}$, Brosnan E, et al. Mumps epidemiology in the mid-west of Ireland 2004-2008: increasing disease burden in the university/college setting. Euro Surveill. 2009;14(16): pii=19182. Available from: http://www.eurosurveillance.org/ ViewArticle.aspx?Articleld $=19182$

2. Mossong J, Bonert C, Weicherding P, Opp M, Reichert P, Even I, et al. Mumps outbreak among the military in Luxembourg in 2008: epidemiology and evaluation of control measures. Euro Surveill. 2009;14(7): pii=19121. Available from: http://www. eurosurveillance.org/ViewArticle.aspx?Articleld=19121

3. Whelan J, van Binnendijk R, Greenland K, Fanoy E, Khargi M, Yap K, et al. Ongoing mumps outbreak in a student population with high vaccination coverage, Netherlands, 2010. Euro Surveill. 2010;15(17): pii=19554. Available from: http://www. eurosurveillance.org/ViewArticle.aspx?Articleld=19554

4. Schmid D, Pichler AM, Wallenko H, Holzmann H, Allerberger F. Mumps outbreak affecting adolescents and young adults in Austria, 2006. Euro Surveill. 2006;11(24):pii=2972. Available from: http://www.eurosurveillance.org/ViewArticle. aspx?Articleld $=2972$

5. Otto W, Mankertz A, Santibanez S, Saygili H, Wenzel J, Jilg W, Wieland WF, Borgmann S. Ongoing outbreak of mumps affecting adolescents and young adults in Bavaria, Germany, August to October 2010. Euro Surveill. 2010;15(50):pii=19748. Available from: http://www.eurosurveillance.org/ViewArticle. aspx?Articleld $=19748$

6. Kuzmanovska G, Polozhani A, Mikik V, Stavridis K, Aleksoski B, Cvetanovska Z, Binnendijk R, Bosevska G. Mumps outbreak in the former Yugoslav Republic of Macedonia, January 2008 - June 2009: epidemiology and control measures. Euro Surveill. 2010;15(23): pii=19586. Available from: http://www. eurosurveillance.org/ViewArticle.aspx?Articleld=19586

7. Hukic M, Ravlija J, Dedeic Ljubovic A, Moro A, Arapcic S, Muller CP, Hübschen JM. Ongoing large mumps outbreak in the Federation of Bosnia and Herzegovina, Bosnia and Herzegovina, December 2010 to July 2011. Euro Surveill. 2011;16(35):pii=19959. Available from: http://www. eurosurveillance. 0 rg/ViewArticle. aspx?Articleld=19959

8. Kay D, Roche M, Atkinson J, Lamden K, Vivancos R. Mumps outbreaks in four universities in the North West of England: Prevention, detection and response. Vaccine 2011;29 (22):3883-7.

9. Heinrich J, Mollema L, Sonder G, Postema C, Binnendijk R, Kohl R, Melker H, Susan Hahné S. Vaccine 2010;28(17):2932-6.

10. Levine H, Ankol O, Rozhavski V, Davidovitch N, Aboudy Y, Zarka S, Balicer R. Vaccine 2011;29(15):2785-2790.

11. Institute of Public Health of Bosnia and Herzegovina. Mjesečni bilten o kretanju zaraznih bolesti veljača/februar 2012. [The monthly newsletter about movement of infectious diseases]. Sarajevo/Mostar: Institute of Public Health FB\&H, 2012. Available from: http://www.zzjzfbih.ba/wp-content/ uploads/2012/02/februar.pdf

12. Institute of Health Protection Regional Institute of East Sarajevo. Bilten o higijensko-epidemiološkoj situaciji na sarajevsko-romaniskoj regiji za mjesec mart 2012. godine. [Bulletin of the hygienic - epidemiological situation in Sarajevo - Romanija region for the month of March 2012.] Institute of Health Protection Regional Institute of East Sarajevo, 2012. Available from: http://www.phi.rs.ba/documents/bilteni/ bilten_2012_03.pdf

13. Statistical Office of the Republic of Serbia. First results of the census of census of population, households and dwellings in the republic of Serbia 2011. Serbian. Available from: http:// popis2011.stat.rs/?lang=cir

14. Slater PE, Roitman M, Costin C. Mumps incidence in Israelimpact of MMR vaccine. Public Health Rev. 1990;91:88-93.

15. Bottiger M, Christenson B, Taranger J, Bergman M. Swedish experience of two dose vaccination programme aimed at eliminating measles, mumps and rubella in Sweden. BMJ. 1987;295:1264-7.

16. Peltola H, Heinonen OP, Valle M, Paunio M, Virtanen M, Karanko V, Cantell K. The elimination of indigenous measles, mumps and rubella from Finland by a 12-year, two-dose vaccination program. New Engl J Med. 1994;331:1397-402.

17. Institute of Public Health of Vojvodina. Communicable diseases in Vojvodina, 2011. Annual report. Serbian. Novi Sad: Institute of Public Health of Vojvodina; 2011.

18. Yung C, Andrews N, Bukasa A, Brown K, Mary Ramsay M. Mumps Complications and Effects of Mumps Vaccination, England and Wales, 2002-2006. Emerging Infectious Diseases 2011;17(4):1-7.

19. Bjorvatn B, Skoldenberg B. Mumps and its complications in Stockholm. BMI. 1978;1:788. 